\title{
Infrared Absorption Spectroscopic Study on Reaction between Self-Assembled Monolayers and Atmospheric-Pressure Plasma
}

\author{
Masanori Shinohara, Katsuhiro Amano, Naoki Maruno, Yuta Yoshida, \\ Yoshinobu Matsuda, and Hiroshi Fujiyama
}

Graduate School of Engineering, Nagasaki University, 1-14 Bunkyo, Nagasaki 852-8521, Japan

Correspondence should be addressed to Masanori Shinohara; sinohara@nagasaki-u.ac.jp

Received 31 October 2014; Revised 25 December 2014; Accepted 8 January 2015

Academic Editor: Renata Diniz

Copyright (C) 2015 Masanori Shinohara et al. This is an open access article distributed under the Creative Commons Attribution License, which permits unrestricted use, distribution, and reproduction in any medium, provided the original work is properly cited.

Plasma is becoming increasingly adopted in bioapplications such as plasma medicine and agriculture. This study investigates the interaction between plasma and molecules in living tissues, focusing on plasma-protein interactions. To this end, the reaction of air-pressure air plasma with $\mathrm{NH}_{2}$-terminated self-assembled monolayer is investigated by infrared spectroscopy in multiple internal reflection geometry. The atmospheric-pressure plasma decomposed the $\mathrm{NH}_{2}$ components, the characteristic units of proteins. The decomposition is attributed to water clusters generated in the plasma, indicating that protein decomposition by plasma requires humid air.

\section{Introduction}

Plasma technology has been adopted in Si-based semiconductor technologies [1-5]. Plasma processing is controlled at the nanoscale in semiconductor device development and is now being applied to new fields [6-9]. Among the promising plasma applications proposed is plasma bioapplication such as plasma medicine $[10-14]$ and plasma agriculture $[15,16]$. To realize these applications, atmospheric-pressure plasma has been developed [14, 17-19]. In addition, we must optimize the plasma effects on organic systems such as human and animal bodies, plants, and seeds. There are numerous cell types containing various proteins, carbohydrates, and adipose molecules. Although plasma bioapplications have been extensively investigated [10-16], the plasma effect is optimized by multiple repeat experiments, the so-called "trialand-error" approach. However, this approach is unsuitable for various biomaterials, because each approach requires a protracted timeframe. Furthermore, trial-and-error approach has failed to clarify the detailed reaction mechanisms of plasma with biomolecules. Understanding these mechanisms will certainly enhance the benefit of plasma bioapplications because a comprehensive understanding will lead to comprehensive methodologies. The major impediment is the difficulty in treating biomolecules because of their great variety, complicated structures, and high molecular weights.

On the other hand, significant information can be gleaned by constructing biomolecule models. Biomolecules with small molecular weights are preferable [20], but it is difficult to analyze their reactions to plasma, because their molecules still have complicated structures with various function groups such as $\mathrm{N}-\mathrm{H}, \mathrm{C}-\mathrm{H}$, and $\mathrm{C}=\mathrm{O}$ bonds. As test molecules for evaluating how plasma reacts with biological tissues, we focus on self-assembled monolayers (SAMs) [21-24], assemblages of monomers deposited on substrate. There are numerous SAMs, each with definitive chemical states and structures and terminated with specific functional group. Furthermore, adipose tissue, proteins, carbohydrates, and other organic molecules contain $-\mathrm{CH}_{2}$ - chains and $-\mathrm{C}-\mathrm{C}-$ bonds, whereas proteins are characterized by the amino $(\mathrm{O}=\mathrm{C}-\mathrm{N}-\mathrm{H},-\mathrm{R},(\mathrm{R}$ : alkyl)) and amine (N-H) groups. We focus on the amine group $(\mathrm{N}-\mathrm{H})$ because of its simple structure. We consider that reactions between plasma and carbohydrate or adipose molecules could be understood by reacting plasma with SAMs that are composed of $-\mathrm{CH}_{2}-$ bonds; similarly, we can understand plasma-protein reactions by reacting plasma with amino-terminated SAMs. Therefore, SAMs present as 


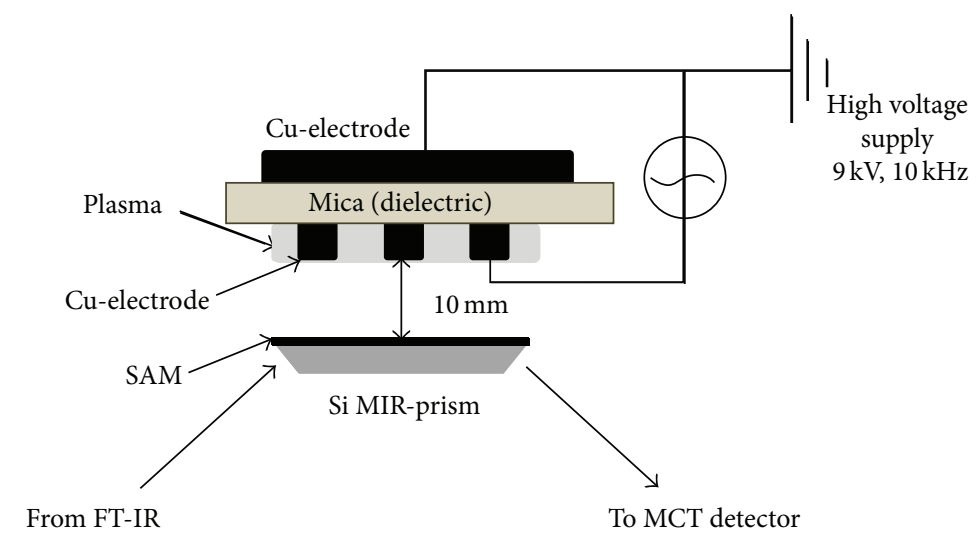

FIGURE 1: Experimental setup.

an ideal tool for research into plasma bioapplications. However, despite elaborate reports of how SAMs interact with plasma generated under low pressure [25-27], the reactions of these mechanisms remain unclear. In particular, unclear are the reactions of $\mathrm{NH}_{2}$-terminated SAM with air plasma at atmospheric pressures. Atmospheric plasma is commonly adopted in bioapplications or plasma medical applications, because living cells naturally exist in atmospheric rather than vacuum conditions. There are not so many papers about interaction between atmospheric-pressure plasma and SAM, although there are elaborate papers about low-pressure plasma treatment on SAMs [28, 29].

In this study, we modeled proteins and fats/carbohydrates by $\mathrm{NH}_{2}$-terminated SAM and $\mathrm{CH}_{3}$-terminated SAM, respectively. Appropriate monomers can form SAMs on a Si surface by siloxane ( $\mathrm{Si}-\mathrm{O})$ bonds [21]. This advantage is particularly beneficial for us, because we have developed "infrared absorption spectroscopy in multiple internal reflection geometry" (MIR-IRAS) using MIR prism made from a Si wafer [30-34]. The study investigates the reaction of atmosphericair plasma with the abovementioned SAM using MIR-IRAS. This technique is suitable to investigate reactions between plasma and SAMs deposited on Si-wafer-based MIR prisms because IR does not interfere with plasma and is too weak to alter the chemical states of SAM.

\section{Experiments}

The MIR-IRAS was monitored by a Fourier-transform IR (FTIR) spectrometer (JASCO FT-6100) and a mercurycadmium-telluride detector. The MIR prisms were made from n-type p-doped double-sided polished $\mathrm{Si}(100)$ wafers with an approximate resistivity of $10 \Omega-\mathrm{cm}$. The prism dimensions were $10 \mathrm{~mm} \times 40 \mathrm{~mm} \times 0.5 \mathrm{~mm}$, with $45^{\circ}$ bevels on each short edge. Each $\mathrm{Si}$ prism was cleaned by conventional RCA cleaning, and its surface was covered with chemical oxides produced in a boiled $\mathrm{H}_{2} \mathrm{SO}_{4} / \mathrm{H}_{2} \mathrm{O}_{2}$ solution. The chemical oxide-covered surface provided the reference spectrum for the IRAS spectrum acquisition. Once the reference data were acquired, the MIR prism surface was recleaned in boiled $\mathrm{H}_{2} \mathrm{SO}_{4} / \mathrm{H}_{2} \mathrm{O}_{2}$ and deposited with two types of SAM. The first was $\mathrm{CH}_{3}$-terminated SAM, obtained by dropping a solution of $2.5 \mathrm{mM}$ octadecyltrichlorosilane (OTS: $\mathrm{Cl}_{3} \mathrm{SiC}_{17} \mathrm{H}_{34} \mathrm{CH}_{3}$, Tokyo Chemical Industry, Tokyo, Japan) in toluene onto the prism surface at RT, followed by sequential rinsing with toluene. Hereafter, this SAM is referred to as OTS-SAM. The second was $\mathrm{NH}_{2}$-terminated SAM, which was obtained in four steps. First, the MIR prism was immersed in $47 \mathrm{mM}$ 3-(2-aminoethylamino)-propyldimethoxymethylsilane $\left(\mathrm{H}_{2} \mathrm{NCH}_{2} \mathrm{CH}_{2} \mathrm{NH}\left(\mathrm{CH}_{2}\right)_{3} \mathrm{Si}\left(\mathrm{OCH}_{3}\right)_{2} \mathrm{CH}_{3}\right.$, Tokyo Chemical Industry, Tokyo, Japan) dissolved in pure water (this step was performed at RT). Second, the sample was dried by annealing at $150^{\circ} \mathrm{C}$ for $1 \mathrm{~h}$ in air. Third, the sample was rinsed with water to remove residual molecules. Fourth, the sample was dried again by annealing for $1 \mathrm{~h}$ in air at $150^{\circ} \mathrm{C}$.

Atmospheric-pressure air plasma source was generated by barrier discharge. For this purpose, a $\mathrm{Cu}$ plate and a $\mathrm{W}$ shaped $\mathrm{Cu}$ wire were affixed to opposite sides of a mica sheet measuring $10 \mathrm{~mm} \times 40 \mathrm{~mm}$. The discharge was applied to the side of the W-shaped wire, which faced the MIR prism, as shown in Figure 1 . The $\mathrm{W}$ fits into a $10 \mathrm{~mm} \times 10 \mathrm{~mm}$ square. The barrier discharge was generated in ambient standard air, dry air, or $\mathrm{N}_{2}$. The dry air was generated by an air compressor equipped with an air dryer (SLP-15EED, Annest Iwata, Yokohama, Japan). The humidity of the dry air should decrease into less than 25\%. SAMs on the MIR prism faced to the grounded electrode, because we want to know mild reaction without irregular atmospheric discharge [18]. The plasma source was set above the MIR prism. During plasma exposure, 80 infrared spectra were acquired at the rate of approximately $1 \mathrm{~min}$ per spectrum. The spectra resolution was $4.0 \mathrm{~cm}^{-1}$.

\section{Results and Discussions}

Figure 2 shows the IR absorption spectrum of the $\mathrm{CH}_{3}$ terminated SAM prepared with OTS in the $\mathrm{C}-\mathrm{H}$ and $\mathrm{O}-$ $\mathrm{H}$ stretching vibration regions. Three peaks are observed at 2850,2920 , and $2950 \mathrm{~cm}^{-1}$. The peaks at 2850 and $2920 \mathrm{~cm}^{-1}$ are attributed to the $\mathrm{CH}_{2}$ components [35] of the OTS-SAM, while that at $2950 \mathrm{~cm}^{-1}$ is attributed to $\mathrm{CH}_{3}$ components [35]. 


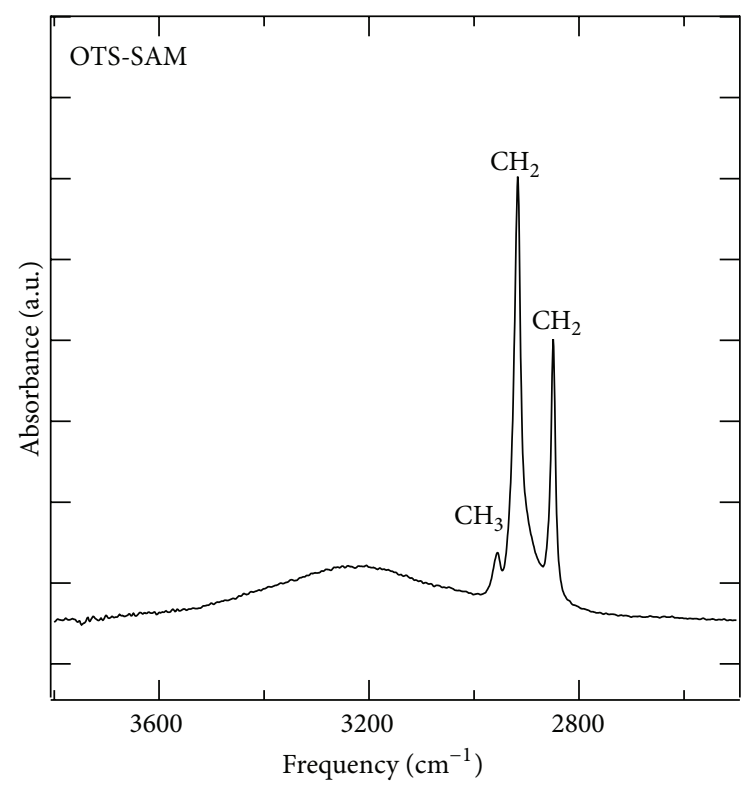

Figure 2: Infrared absorption spectrum of OTS-SAM.

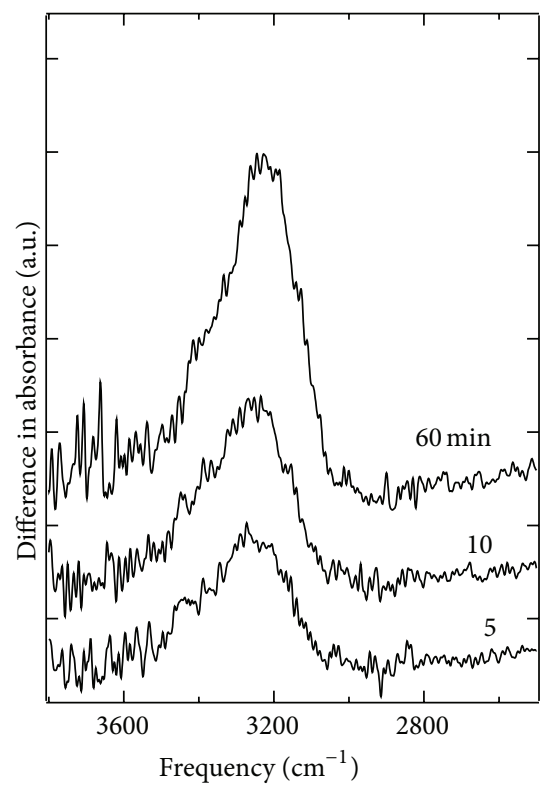

Figure 3: Differences between the infrared absorption spectra of the OTS-SAM obtained before and after exposure to air-pressure air plasma (exposure time in minutes).

The $\mathrm{CH}_{3}$ peak is considerably less intense than the $\mathrm{CH}_{2}$ peaks. This intensity disparity reflects the chemical bonding structure of the OTS-SAM; each of its monomers comprises $17 \mathrm{CH}_{2}$ components and one $\mathrm{CH}_{3}$ component. The peak at $3200 \mathrm{~cm}^{-1}$ is attributed to $\mathrm{OH}$ [35], which is absent in the monomers, so the peak must arise from adsorption of water in air during the measurement.

Figure 3 shows the IR absorption spectra of the OTSSAM exposed to atmospheric-pressure air plasma for various periods, in comparison with the spectrum of the SAM before plasma exposure, in order to clarify spectral changes. The vertical axis indicates absorbance differences with respect to the spectrum of the SAM before plasma exposure. The figure shows the absorbance differences between the two spectra (vertical axis). The peak between 3200 and $3300 \mathrm{~cm}^{-1}$, whose location is consistent with hydrogen-bonded water, becomes more intense after the exposure. We suggest that water clusters are generated by the atmospheric-pressure air plasma and become absorbed on the OTS-SAM, although we need crosschecking with other methods such as mass spectroscopy. We will perform checking in the near future. This proposition is consistent with previous reports, in which clustered water was generated in air by electrical discharge [36-38]. On the other hand, these changes are absent in the $\mathrm{CH}$ stretching vibration region (between 2800 and $3000 \mathrm{~cm}^{-1}$ ). This indicates that the $-\mathrm{CH}_{2}$ - and $-\mathrm{CH}_{3}$ components in the OTS-SAM are stable against charged water clusters generated in the atmosphericpressure air plasma. This finding nullifies the rapid generation of oxidizing species such as oxygen radicals in the atmospheric-pressure air plasma because such species would affect the $-\mathrm{CH}_{3}$ and $-\mathrm{CH}_{2}-$ chains. We have confirmed that the $\mathrm{CH}_{3}$ and $\mathrm{CH}_{2}$ components in the OTS-SAM are etched by the oxygen plasma exposure generated in low pressure oxygen ambience, although the experimental condition is different. The details are described in another paper [39]. We speculate that the atmospheric-pressure plasma generates not only oxygen radicals but also water cluster. We need to know the generated species beside water cluster and their density; moreover for the plasma itself we need to know how much power is consumed by plasma and what is gas temperature. We will investigate them in the near future.

Figure 4 shows the IR absorption spectrum of the $\mathrm{NH}_{2}$ terminated SAM prepared in this study. In Figure 4(a), a broad band is observed between 3000 and $3500 \mathrm{~cm}^{-1}$, which is attributed to $\mathrm{N}-\mathrm{H}$ and $\mathrm{O}-\mathrm{H}$ stretching vibrations. This band is broadened by the $\mathrm{O}-\mathrm{H}$ vibration modes which, as observed in Figure 2, are attributed to $\mathrm{O}-\mathrm{H}$ of water adsorbed from the air. The other broad band between 1200 and $1600 \mathrm{~cm}^{-1}$ (Figure 4(b)) is attributed to the bending modes of $\mathrm{N}-\mathrm{H}$ and $\mathrm{O}-\mathrm{H}$. The prominent peaks at 1480 and $1580 \mathrm{~cm}^{-1}$ arise from the bending modes of $\mathrm{N}-\mathrm{H}$ [35]. It might be hardly capable to form well-defined monolayer because of the fact that the source monomer is short-chain molecules. And also the SAM contains both $\mathrm{NH}_{2}$ and $\mathrm{NH}$ groups in different positions within the backbone. We might not be able to elucidate the detailed interaction between $\mathrm{NH}_{2}$ and atmospheric-pressure plasma because of these reasons. However, we can investigate the reactivity of $\mathrm{N}-\mathrm{H}$ bonds, included in $\mathrm{NH}$ and $\mathrm{NH}_{2}$, respective to the plasma, with MIR-IRAS. The reactivity is very important to proteins that include $\mathrm{N}-\mathrm{H}$ bonds. We consider that the SAM used in this study is suitable to investigate the reaction of $\mathrm{N}-\mathrm{H}$ bonds with atmospheric-pressure plasma in the present.

Figure 5 compares the IR absorption spectra of the $\mathrm{NH}_{2}$-terminated SAM before and after exposure to the atmospheric-pressure air plasma. As in Figure 3, the vertical axis indicates the absorbance differences between the spectra. Figure 5(a) shows the $\mathrm{C}-\mathrm{H}, \mathrm{O}-\mathrm{H}$, and $\mathrm{N}-\mathrm{H}$ stretching 


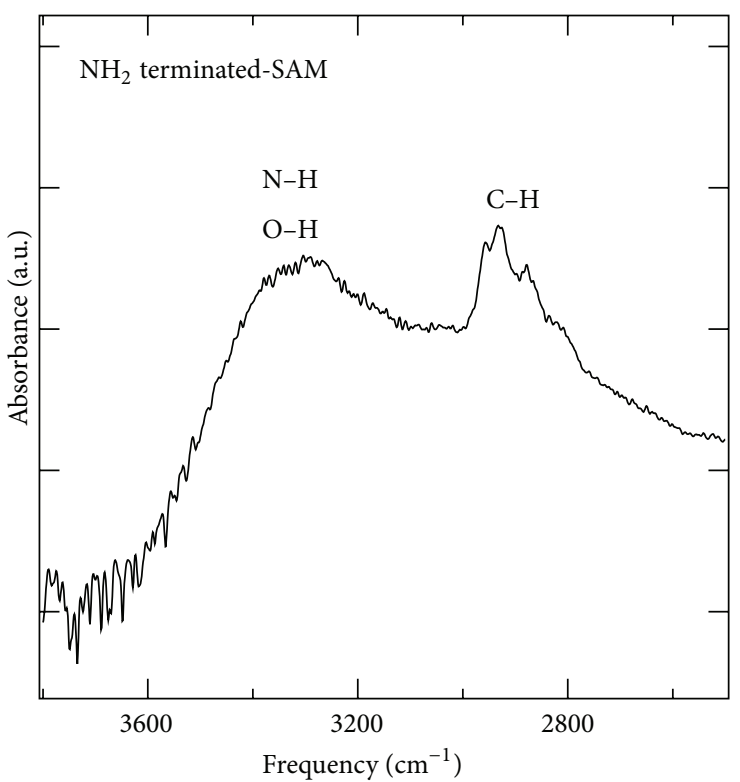

(a)

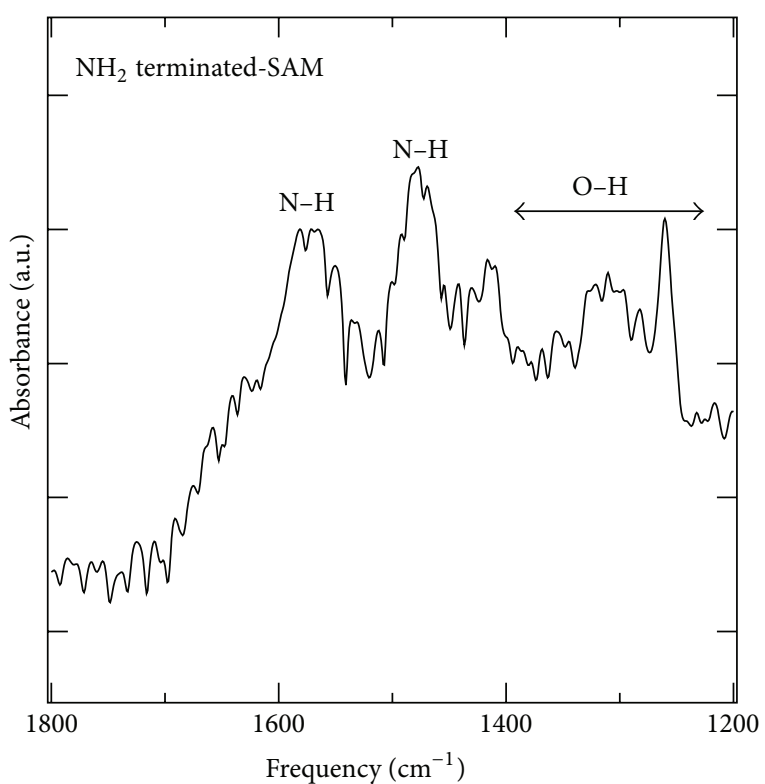

(b)

FIGURE 4: Infrared absorption spectrum of $\mathrm{NH}_{2}$-teminated SAM: (a) in the bending and deformation vibration region and (b) in the stretching vibration region.

vibration regions between 2700 and $3700 \mathrm{~cm}^{-1}$. Following exposure to plasma, the peak intensity between 3200 and $3400 \mathrm{~cm}^{-1}$ decreases, while that between 3000 and $3200 \mathrm{~cm}^{-1}$ increases. The former and latter peaks are attributed to primary amines $\left(\mathrm{NH}_{2}\right)$ and $\mathrm{OH}$, respectively. The $\mathrm{OH}$ peak is observed between 3200 and $3400 \mathrm{~cm}^{-1}$ in the plasmaexposed OTS-SAM (Figure 3), suggesting that the $\mathrm{OH}$ peak shifts to the lower vibration region. The peak of $\mathrm{OH}$ adjacent to $\mathrm{N}$ atoms shifts into the lower vibration region. Thus, we can assign the peak between 3000 and $3200 \mathrm{~cm}^{-1}$ to the $\mathrm{O}-\mathrm{H}$ of oximes $(\mathrm{OH}-\mathrm{N}=\mathrm{C}-\mathrm{R}, \mathrm{H})$ [27]. The number of $\mathrm{N}-\mathrm{H}$ groups decreased after plasma exposure, while that of $\mathrm{OH}$ groups bonded to $\mathrm{N}$ atoms increased. The peak intensity attributed to $\mathrm{N}-\mathrm{H}$ decreased after less than 10 minutes of plasma exposure and remained relatively steady thereafter (up to $60 \mathrm{~min}$ exposure). On the other hand, the intensity of the oxime $\mathrm{O}-\mathrm{H}$ peak gradually increased throughout the 60-minute exposure period. The bending mode region between 1200 and $1800 \mathrm{~cm}^{-1}$ is visible in Figure 5(b). The doublet peaks at 1540 and $1480 \mathrm{~cm}^{-1}$ are attributed to the $\mathrm{N}-\mathrm{H}$ bending mode, and the broad peak between 1300 and $1400 \mathrm{~cm}^{-1}$ is attributed to the $\mathrm{O}-\mathrm{H}$ bending modes. The intensity of the peak attributed to $\mathrm{NH}$ components remarkably decreased during the first 5 minutes of exposure but remained steady thereafter. On the other hand, the intensity of the peaks attributed to O$\mathrm{H}$ components gradually and steadily increased throughout the exposure period. The intensity changes in the $\mathrm{N}-\mathrm{H}$ and $\mathrm{O}-\mathrm{H}$ peaks exhibit the same behavior in Figures 5(a) and $5(b)$, indicating that $\mathrm{NH}$ is decomposed before the $\mathrm{OH}$ is adsorbed. When water clusters reach the $\mathrm{NH}_{2}$-terminated $\mathrm{SAM}$, the $\mathrm{NH}_{2}$ group might become dehydrated by an oxidation process, with formation of $\mathrm{OH}-\mathrm{N}$ bonds such as oximes. Moreover, the $\mathrm{N}-\mathrm{H}$ peak reduces before the $\mathrm{O}-\mathrm{H}$ peak increases, suggesting that the $\mathrm{N}-\mathrm{H}$ group decomposed before O-H adsorption. The OTS-SAM results confirmed that water clusters were generated in the applied atmosphericpressure air plasma. Therefore, we can interpret plasma reactions with $\mathrm{NH}_{2}$-terminated SAM in terms of the charged water clusters generated during plasma exposure. Of course, uncharged water clusters would not have decomposed the $\mathrm{NH}_{2}$-terninated SAM, because the SAM is produced in water.

Given the importance of humid air in the proposed reaction model of $\mathrm{NH}_{2}$-terminated SAM-plasma interactions, we altered the plasma atmosphere from air to dry air or $\mathrm{N}_{2}$ gas. Note that humid air contains humidity of more than $50 \%$, while dry air contains that of less than $25 \%$ as described in Experiment section. Figure 6 shows the infrared absorption spectra of $\mathrm{NH}_{2}$-terminated SAM exposed to plasma generated in air, dry air, or $\mathrm{N}_{2}$ gas for $60 \mathrm{~min}$. The $\mathrm{N}-\mathrm{H}$ peak decreased only under an air atmosphere. Although the O$\mathrm{H}$ peak formed under both dry air and $\mathrm{N}_{2}$, the $\mathrm{N}-\mathrm{H}$ peak remained stable in these atmospheres. In dry air and $\mathrm{N}_{2}$ gas, $\mathrm{OH}$ formation is attributed to the oxidation of the $\mathrm{SAM}$ by $\mathrm{O}_{2}$ and residual oxygen, respectively, but the $\mathrm{NH}_{2}$ groups remain intact. These results confirm that charged water clusters are required for decomposition of amine components. This study suggested that humid air is required for sterilization due to atmospheric-pressure plasma, because of the decomposition of amine group characteristic to proteins inevitable to a living thing such as virus and bacteria.

\section{Conclusions}

The reactions between plasma and two SAM types were investigated using infrared absorption spectroscopy in multiple internal reflection geometry. Atmospheric-pressure air 


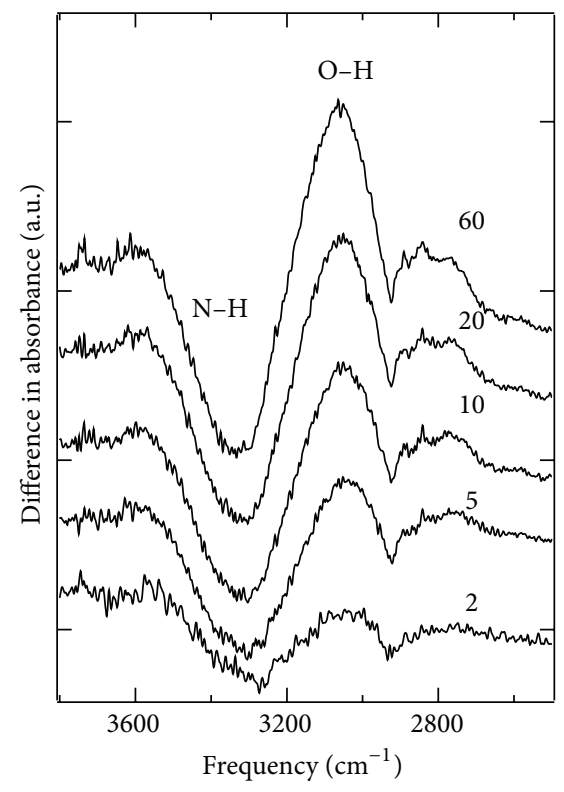

(a)

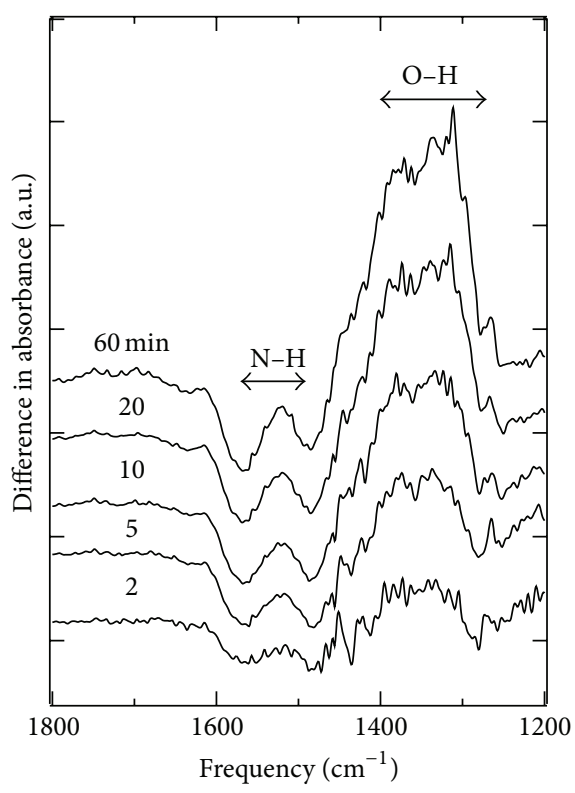

(b)

FIGURE 5: Differences between the infrared absorption spectra of the $\mathrm{NH}_{2}$-teminated SAM obtained before and after exposure to air-pressure air plasma (exposure time in minutes): (a) in the stretching vibration region and (b) in the bending and deformation vibration regions.

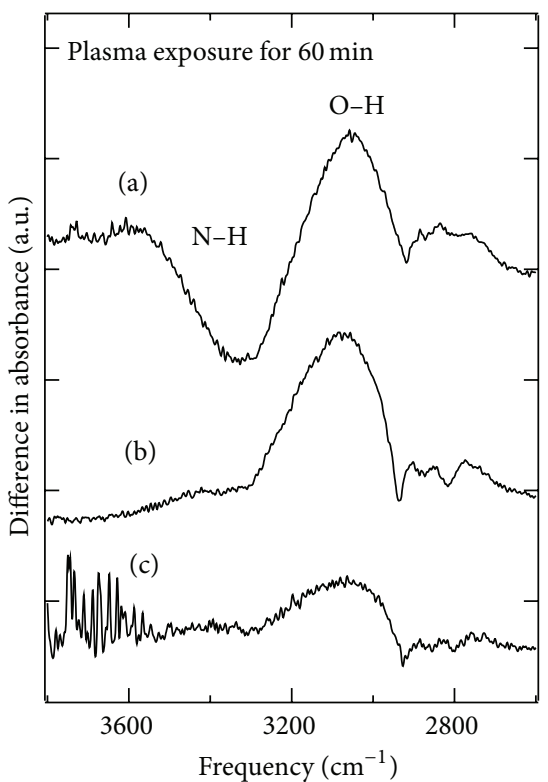

FIGURE 6: Differences between the infrared absorption spectra of $\mathrm{NH}_{2}$-teminated SAM in the stretching vibration region, obtained before and after a 30 min exposure to air-pressure plasma generated under different atmospheres: (a) standard air, (b) dry air, and (c) $\mathrm{N}_{2}$ gas.

plasma generated hydrogen-bonded water by barrier discharge in air. Plasma exposure did not affect the $\mathrm{CH}_{3}$ terminated OTS-SAM film but oxidized the $\mathrm{NH}_{2}$-terminated $\mathrm{SAM}$; in the latter SAM, the number of $\mathrm{O}-\mathrm{H}$ components was increased at the expense of the $\mathrm{N}-\mathrm{H}$ groups. We also clarified that humid air is required for decomposition of amine groups by the applied plasma. This study indicates that humid air is required for sterilization due to air pressure plasma.

\section{Conflict of Interests}

The authors declare that there is no conflict of interests regarding the publication of this paper.

\section{Acknowledgments}

Parts of this work were supported by the following grants from the Ministry of Education, Culture, Sports, Science and Technology of Japan (MEXT) and Japan Society for the Promotion of Science (JSPS): a Grant-in-Aid for Scientific Research on Innovative Areas (Material design), MEXT KAKENHI Grant no. 25104720 (2013-2016), a Grantin-Aid for Scientific Research (B) JSPS KAKENHI Grant no. 24340144 (2012-2015), and Grants-in-Aid for Scientific Research on Innovative Areas (Plasma-nano interface) (MEXT KAKENHI Grant no. 22110511 (2010-2012) and no. 24110716 (2012-2014).

\section{References}

[1] G. Lucovsky, P. D. Richard, D. V. Tsu, S. Y. Lin, and R. J. Markunas, "Deposition of silicon dioxide and silicon nitride by remote plasma enhanced chemical vapor deposition," Journal of Vacuum Science \& Technology A, vol. 4, no. 3, article 681, 1986.

[2] A. Matsuda, "Plasma and surface reactions for obtaining low defect density amorphous silicon at high growth rates," Journal of Vacuum Science \& Technology A, vol. 16, no. 1, pp. 365-368, 1998. 
[3] R. D’Agostino, P. Favia, C. Oehr, and M. R. Wertheimer, "Lowtemperature plasma processing of materials: past, present, and future," Plasma Processes and Polymers, vol. 2, no. 1, pp. 7-15, 2005.

[4] J. Shoeb, M. M. Wang, and M. J. Kushner, "Damage by radicals and photons during plasma cleaning of porous low- $k \mathrm{SiOCH}$. I. $\mathrm{Ar} / \mathrm{O}_{2}$ and $\mathrm{He} / \mathrm{H}_{2}$ plasmas," Journal of Vacuum Science \& Technology A: Vacuum, Surfaces and Films, vol. 30, no. 4, Article ID 041303, 2012.

[5] V. M. Donnelly and A. Kornblit, "Plasma etching: yesterday, today, and tomorrow," Journal of Vacuum Science and Technology A: Vacuum, Surfaces and Films, vol. 31, no. 5, Article ID 050825, 2013.

[6] C.-J. Liu, J. Zou, K. Yu et al., "Plasma application for more environmentally friendly catalyst preparation," Pure and Applied Chemistry, vol. 78, no. 6, pp. 1227-1238, 2006.

[7] K. Yamamoto, T. Sato, K. Takahara, and K. Hanaguri, "Properties of ( $\mathrm{Ti}, \mathrm{Cr}, \mathrm{Al}) \mathrm{N}$ coatings with high $\mathrm{Al}$ content deposited by new plasma enhanced arc-cathode," Surface and Coatings Technology, vol. 174-175, pp. 620-626, 2003.

[8] E. Pfender, "Thermal plasma technology: where do we stand and where are we going?" Plasma Chemistry and Plasma Processing, vol. 19, no. 1, pp. 1-31, 1999.

[9] Y. Tanaka, T. Nagumo, H. Sakai, Y. Uesugi, Y. Sakai, and K. Nakamura, "Nanoparticle synthesis using high-powered pulsemodulated induction thermal plasma," Journal of Physics D: Applied Physics, vol. 43, no. 26, Article ID 265201, 2010.

[10] G. Fridman, G. Friedman, A. Gutsol, A. B. Shekhter, V. N. Vasilets, and A. Fridman, "Applied plasma medicine," Plasma Processes and Polymers, vol. 5, no. 6, pp. 503-533, 2008.

[11] S. Iseki, K. Nakamura, M. Hayashi et al., "Selective killing of ovarian cancer cells through induction of apoptosis by nonequilibrium atmospheric pressure plasma," Applied Physics Letters, vol. 100, no. 11, Article ID 113702, 2012.

[12] M. Laroussi, "Low-temperature plasmas for medicine?" IEEE Transactions on Plasma Science, vol. 37, no. 6, pp. 714-725, 2009.

[13] M. Keidar, R. Walk, A. Shashurin et al., "Cold plasma selectivity and the possibility of a paradigm shift in cancer therapy," British Journal of Cancer, vol. 105, no. 9, pp. 1295-1301, 2011.

[14] T. von Woedtke, S. Reuter, K. Masur, and K.-D. Weltmann, "Plasmas for medicine," Physics Reports, vol. 530, no. 4, pp. 291320, 2013.

[15] B. Šerá, P. Špatenka, M. Šerý, N. Vrchotová, and I. Hrušková, "Influence of plasma treatment on wheat and oat germination and early growth," IEEE Transactions on Plasma Science, vol. 38, no. 10, pp. 2963-2968, 2010.

[16] S. Kitazaki, K. Koga, M. Shiratani, and N. Hayashi, "Growth enhancement of radish sprouts induced by low pressure o 2 radio frequency discharge plasma irradiation," Japanese Journal of Applied Physics, vol. 51, no. 1, Article ID 01AE01, 2012.

[17] X. Lu, M. Laroussi, and V. Puech, "On atmospheric-pressure non-equilibrium plasma jets and plasma bullets," Plasma Sources Science and Technology, vol. 21, no. 3, Article ID 034005, 2012.

[18] X. Lu, G. V. Naidis, M. Laroussi, and K. Ostrikov, "Guided ionization waves: theory and experiments," Physics Reports, vol. 540, no. 3, pp. 123-166, 2014.

[19] M. Teschke, J. Kedzierski, E. G. Finantu-Dinu, D. Korzec, and J. Engemann, "High-speed photographs of a dielectric barrier atmospheric pressure plasma jet," IEEE Transactions on Plasma Science, vol. 33, no. 2, pp. 310-311, 2005.
[20] Y. Setsuhara, K. Cho, M. Shiratani, M. Sekine, and M. Hori, "Plasma interactions with aminoacid (l-alanine) as a basis of fundamental processes in plasma medicine," Current Applied Physics, vol. 13, supplement 1, pp. S59-S63, 2013.

[21] A. Ulman, "Formation and structure of self-assembled monolayers," Chemical Reviews, vol. 96, no. 4, pp. 1533-1554, 1996.

[22] C. D. Bain and G. M. Whitesides, "Modeling organic-surfaces with self-assembled monolayers," Angewandte Chemie International Edition, vol. 28, no. 4, pp. 506-512, 1989.

[23] C. E. D. Chidsey and D. N. Loiacono, "Chemical functionality in self-assembled monolayers: structural and electrochemical properties," Langmuir, vol. 6, no. 3, pp. 682-691, 1990.

[24] N. Faucheux, R. Schweiss, K. Lützow, C. Werner, and T. Groth, "Self-assembled monolayers with different terminating groups as model substrates for cell adhesion studies," Biomaterials, vol. 25, no. 14, pp. 2721-2730, 2004.

[25] F. M. Elms and G. A. George, "Plasma reactions of selfassembled monolayers to model oxygen atom effects on polymers," Polymers for Advanced Technologies, vol. 9, no. 1, pp. 3137, 1998.

[26] M. Tatoulian, O. Bouloussa, F. Morière, F. Arefi-Khonsari, J. Amouroux, and F. Rondelez, "Plasma surface modification of organic materials: comparison between polyethylene films and octadecyltrichlorosilane self-assembled monolayers," Langmuir, vol. 20, no. 24, pp. 10481-10489, 2004.

[27] J. Torres, C. C. Perry, S. J. Bransfield, and D. H. Fairbrother, "Radical reactions with organic thin films: chemical interaction of atomic oxygen with an X-ray modified self-assembled monolayer," Journal of Physical Chemistry B, vol. 106, no. 24, pp. 62656272, 2002.

[28] K. Raiber, A. Terfort, C. Benndorf, N. Krings, and H.-H. Strehblow, "Removal of self-assembled monolayers of alkanethiolates on gold by plasma cleaning," Surface Science, vol. 595, no. 1-3, pp. 56-63, 2005.

[29] M. Tatoulian, O. Bouloussa, F. Morière, F. Arefi-Khonsari, J. Amouroux, and F. Rondelez, "Plasma surface modification of organic materials: comparison between polyethylene films and octadecyltrichlorosilane self-assembled monolayers," Langmuir, vol. 20, no. 24, pp. 10481-10489, 2004.

[30] M. Shinohara, A. Seyama, Y. Kimura, M. Niwano, and M. Saito, "Formation and decomposition of Si hydrides during adsorption of $\mathrm{Si}_{2} \mathrm{H}_{6}$ onto $\mathrm{Si}(100)(2 \times 1)$," Physical Review BCondensed Matter and Materials Physics, vol. 65, no. 7, Article ID 075319, 2002.

[31] M. Shinohara, T. Kuwano, Y. Akama et al., "Interaction of hydrogen-terminated $\mathrm{Si}(100)$, (110), and (111) surfaces with hydrogen plasma investigated by in situ real-time infrared absorption spectroscopy," Journal of Vacuum Science \& Technology A, vol. 21, no. 1, pp. 25-31, 2003.

[32] M. Shinohara, K. Cho, H. Shibata et al., "Interaction between hydrogen plasma and hydrogenated amorphous carbon film, investigated by infrared spectroscopy," Thin Solid Films, vol. 516, no. 13, pp. 4379-4383, 2008.

[33] M. Shinohara, H. Kawazoe, T. Inayoshi et al., "Difference of deposition process of an amorphous carbon film due to source gases," Thin Solid Films, vol. 518, no. 13, pp. 3497-3501, 2010.

[34] M. Shinohara, A. Fuakae, K. Amano, Y. Yoshida, Y. Matsuda, and H. Fujiyama, "Development of an in situ infrared spectroscopic measurement of plasma-induced reactions in ethanol," Japanese Journal of Applied Physics, vol. 52, no. 11, Article ID 11NC06, 2013. 
[35] G. Socrates, Infrared and Raman Characteristic Group Frequencies, John Wiley \& Sons, Chichester, UK, 3rd edition, 2001.

[36] M. M. Shahin, "Mass-spectrometric studies of corona discharges in air at atmospheric pressures," The Journal of Chemical Physics, vol. 45, no. 7, pp. 2600-2605, 1966.

[37] A. W. Castleman Jr. and R. G. Keesee, "Ionic clusters," Chemical Reviews, vol. 86, no. 3, pp. 589-618, 1986.

[38] H. Haberland, H. Langosch, H.-G. Schindler, and D. R. Worsnop, "Negatively charged water clusters: mass spectra of $\left(\mathrm{H}_{2} \mathrm{O}\right)_{n^{-}}$and $\left(\mathrm{D}_{2} \mathrm{O}\right)_{n^{-}}$," Journal of Physical Chemistry, vol. 88, no. 17, pp. 3903-3904, 1984.

[39] M. Shinohara, N. Maruno, Y. Yoshida et al., "Infrared spectroscopic study of the reactions between an octadecyltrichlorosilane self-assembled monolayer and plasma," Japanese Journal of Applied Physics, vol. 54, Article ID 01AB04, 2015. 

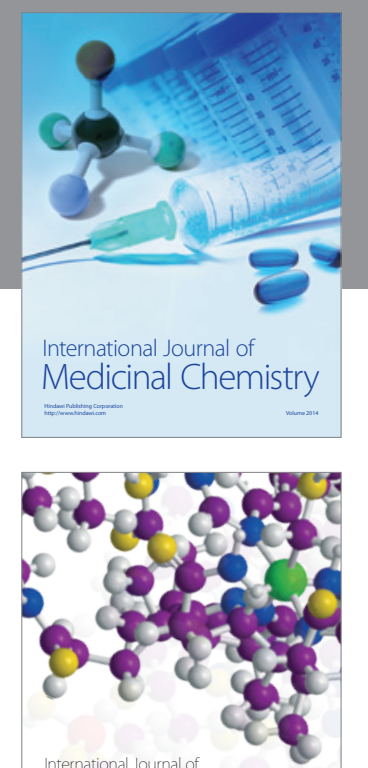

\section{Carbohydrate} Chemistry

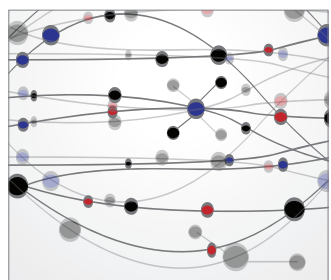

The Scientific World Journal
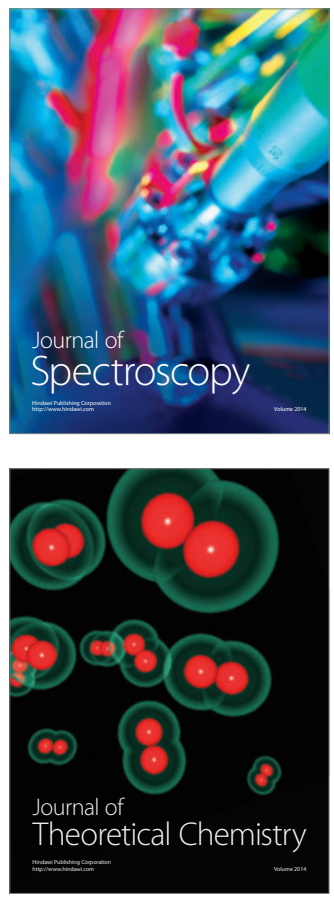
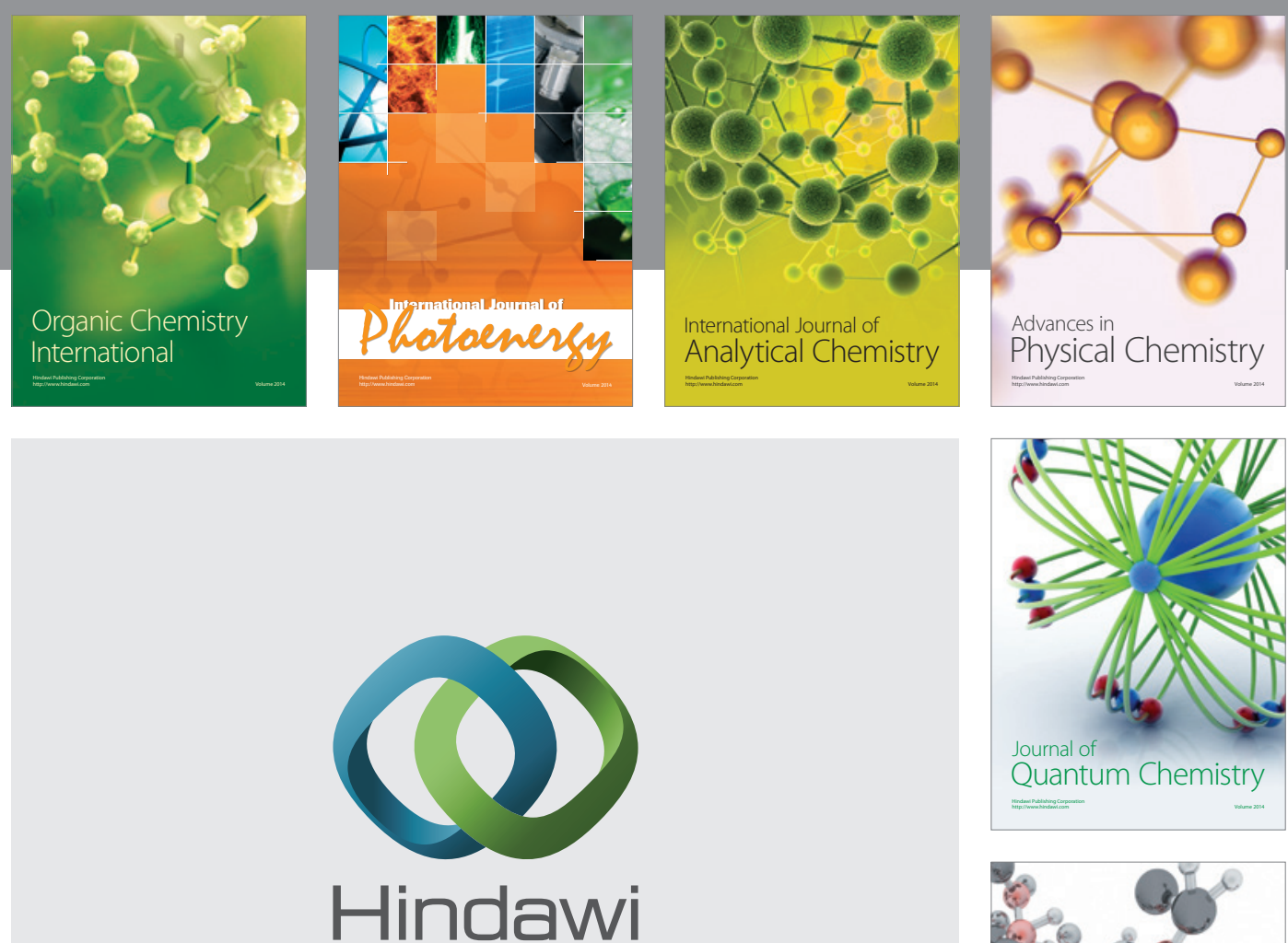

Submit your manuscripts at

http://www.hindawi.com

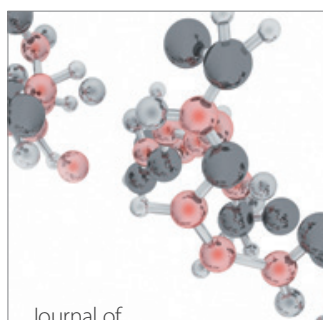

Analytical Methods

in Chemistry

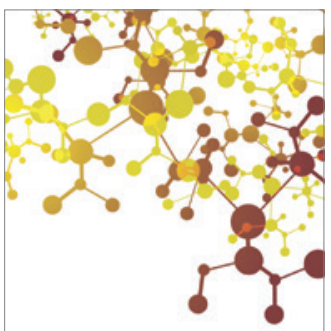

Journal of

Applied Chemistry

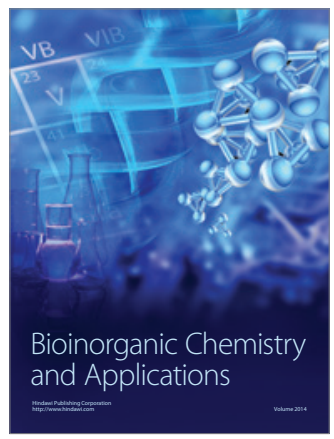

Inorganic Chemistry
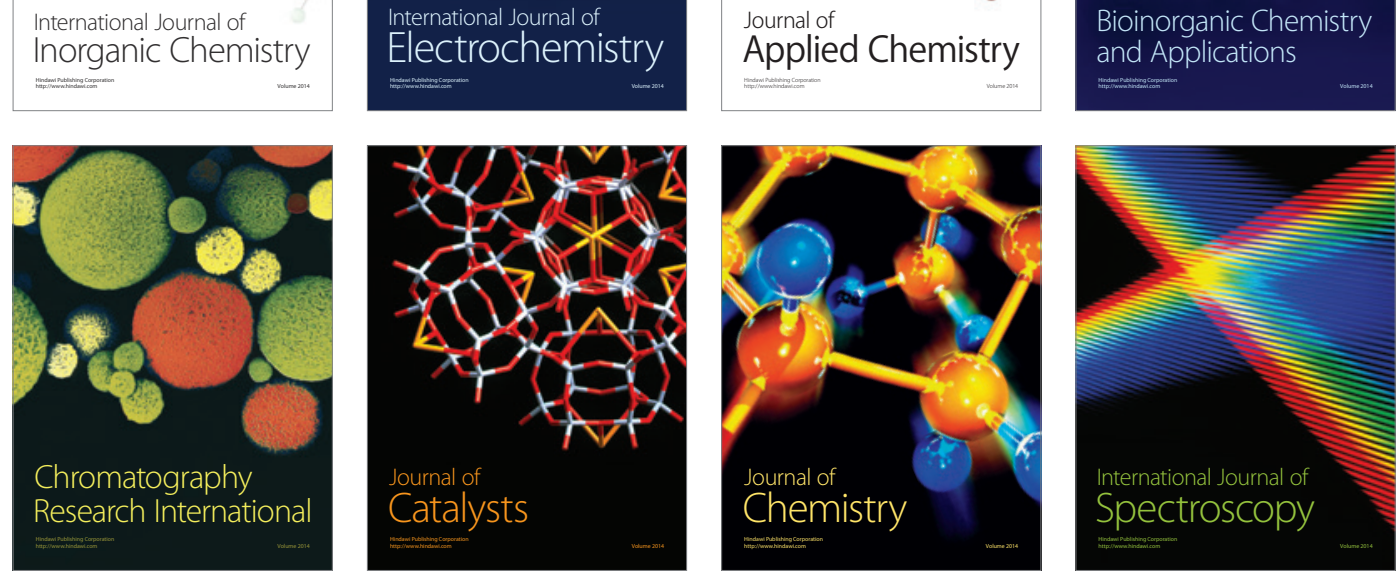